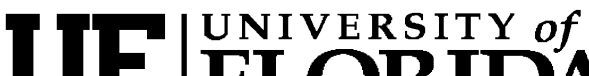 FLORIDA \\ IFAS Extension
}

\section{Community Support of Sexual Minority Adolescents ${ }^{1}$}

\section{Christine Regan and Kate Fogarty ${ }^{2}$ \\ Introduction}

Community-based organizations and programs that work with youth can have a tremendous, positive impact on the development of our nation's children. Organizations have the potential to provide opportunities for youth to acquire personal and social assets, and experience features of positive developmental settings, such as teamwork, diversity, citizenship, leadership, character development, and well-being (Benson, 1997).

Specifically, community-based organizations and programs have an opportunity to reach sexual minority or lesbian, gay, bisexual, and transgender (LGBT) adolescents. Rather than neglect and/or stigmatize these adolescents, organizations can model openness and teach both adolescent peers and mentors how to respect and appreciate differences as well as similarities. The purpose of this publication is to provide staff and volunteers working in community-based settings with positive information and practical tips on how to create a welcoming, safe environment for LGBT adolescents.

The first programmatic decision that needs to be made is whether the organization and its stakeholders are prepared to openly offer support to sexual minority youth. Community organizations are not always supportive or inclusive of gay and lesbian issues (Keefer \& Reene, 2002). Providing support to sexual minority youth may be difficult for some organizational settings and stakeholders. This difficulty may be motivated by fear of organizational change, lack of commitment to the issue, decreased importance of following through, and unrealistic or incorrect views about homosexuality (for example, viewing sexual minority youth as sexual perpetrators or as having a mental disorder). Creating organizational change to openly support sexual minority youth may be difficult. If this is the case in your organization, consider applying some of the more subtle tips from this article to your own practice. This may help to set an example with colleagues. Even small actions will help integrate, rather than alienate, sexual minority youth into your community program.

\section{Practical tips}

Here are some practical tips on how adults can create a safe, supportive, and welcoming atmosphere for sexual minority adolescents. For helpful internet resources, continue to the end of the document.

1. This document is FYCS 9234, one of a series of the Department of Family, Youth and Community Sciences, Cooperative Extension Service, Institute of Food and Agricultural Sciences, University of Florida. Publication date: August 2006. Please visit the EDIS website at http://edis.ifas.ufl.edu

2. Christine Regan, Master of Science candidate, and Kate Fogarty, assistant professor, both of the Department of Family, Youth and Community Sciences, Cooperative Extension Service, Institute of Food and Agricultural Sciences, University of Florida, Gainesville, FL, 32611.

The Institute of Food and Agricultural Sciences (IFAS) is an Equal Opportunity Institution authorized to provide research, educational information and other services only to individuals and institutions that function with non-discrimination with respect to race, creed, color, religion, age, disability, sex, sexual orientation, marital status, national origin, political opinions or affiliations. U.S. Department of Agriculture, Cooperative Extension Service, University of Florida, IFAS, Florida A. \& M. University Cooperative Extension Program, and Boards of County Commissioners Cooperating. Larry Arrington, Dean 
- Learn more about the challenges LGBT adolescents face with their peers, families, and community and how they develop their identity.

- Seek out personal stories of what LGBT adolescents actually experience.

- Display "safe space" rainbow stickers in offices or on doors in your community center.

- Create a supportive atmosphere for youth to explore and talk about their sexual identities with you.

- Correct a co-worker,or friend when she/he makes an anti-gay remark to an adolescent or adult mentor.

- In the case of a youth making an anti-gay remark to friends, have a one-on-one discussion about the impact of these comments with him or her.

- Help develop gay-straight alliances or other support groups for gay, lesbian, bisexual, transgender, heterosexual, and questioning youth who may want to talk to each other about issues related to sexual orientation and gender identity.

- Provide adolescents with information about local or national resources within the gay, lesbian, bisexual, and transgender community, when appropriate.

- Develop talking points based on the different stages of homosexual identity formation and share this information with adult and youth audiences.

- Organize and/or participate in workshops or seminars which give counseling strategies for dealing with sexual minority youth.

- Advocate for changes in organizational climate, curriculum used, and, ultimately, policy that positively affects the lives of sexual minority adolescents.

- Provide counseling that is appropriate to a youth's stage of homosexual identity development. For example, an adolescent who appears to be confused about her or his identity might need: support to express thoughts and feelings; readings or information about homosexual identity; acceptance of "differentness;" and discouragement of premature labeling. It is important to allow the adolescent to decipher if any label truly fits them, rather than adopt one immediately.

\section{Resources for adults who work with youth (also see national organizations below)}

- The American Psychological Association's Healthy Lesbian, Gay, and Bisexual Students Project works with schools to help prevent risky behaviors and improve health outcomes for lesbian, gay, and bisexual youth. http://www.apa.org/ed/hlgb/

- The Gay and Straight Educators Network combats harassment and discrimination of gay students and school personnel. http://www.glsen.org/cgi-bin/iowa/educator/ educator/index.html

- The NEA's "Strengthening the Learning Environment: An Education Employee's Guide to Gay and Lesbian Issues." http://www.nea.org/nr/02taskforce.html

- Parents and Friends of Lesbians and Gays. http://www.pflag.org/index.php?id=83\#1

\section{Resources for youth}

- Book resources. http://www.bidstrup.com/parbiblio.htm

- Campus Pride. http://www.campuspride.net

- Coming out Stories. http://www.rslevinson.com/gaylesissues/ comingoutstories/blcoming_youth.htm

- Equality Ride. http://www.equalityride.com

- Gay and Lesbian National Hotline. http://www.glnh.org/index.html

- Gay Health. http://www.gayhealth.com/templates/0/ index.html 
- Gay Youth Corner. http://www.thegyc.com

- Outproud. http://www.outproud.org

- Queer America. http://www.queeramerica.com/

- Young Gay America.

http://www.younggayamerica.com/index1.shtml

- Youth.org. http://www.youth.org/

- Youthline. http://www.youthline.ca/

- Youth Resource. http://www.youthresource.com

\section{National organizations that support sexual minority adolescents}

- American Academy of Child and Adolescent

Psychiatry. http://www.aacap.org

- American Psychological Association. http://www.apa.org/pi/lgbc/policy/pshome.html

- American School Counselor Association. http://www.schoolcounselor.org

- Association of Gay and Lesbian Psychiatrists. http://www.aglp.org

- Human Rights Campaign. http://www.hrc.org

- Human Rights Watch. http://www.hrw.org

- National Association of School Psychologists. http:// www.nasponline.org

- National Education Association.

http://www.nea.org

- National Gay and Lesbian Task Force.

http://www.thetaskforce.org/

- National Mental Health Association. http://www.nmha.org/pbedu/backtoschool/ bullyingGayYouth.cfm

\section{Religious organizations that support sexual minority adolescents}

- Affirmation: (Latter Day Saints).

http://www.affirmation.org/
- Affirmation: (United Methodists). http://www.umaffirm.org/

- Association of Welcoming and Affirming Baptists. http://www.wabaptists.org/

- Christian Alliance for Progress. http://www.christianalliance.org/

- Friends for LGBTQ Concerns (Quakers). http://www.quaker.org/flgbtqc/

- Integrity (Episcopalian). http://www.integrityusa.org/

- Lutherans Concerned. http://www.lcna.org/

- Metropolitan Community Church. http://mecchurch.org/

- Presbyterian for LGTBQ Concerns. http://www.mlp.org/

- Seventh-Day Adventist Kinship. http://www.sdakinship.org/

- Soul Force (All faiths). http://www.soulforce.org/

- Truth Sets Free (All faiths). http://www.truthsetsfree.net/

- Unity Fellowship of Church of Christ. http://www.ufc-usa.org/

- World Congress of LGBT Jews. http://glbtjews.org/

\section{References}

Benson, Peter L. (1997). All Kids Are Our Kids. San Francisco: Jossey-Bass. 